\title{
An Extra Small Metacentric Autosome in a Mentally Retarded Boy with Multiple Malformations
}

\author{
SALVADOR ARMENDARES,* LEONOR BUENTELLO, and FABIO SALAMANCA \\ From the Genetics Section of the Department of Investigation and the Department of Medical Genetics of the \\ Paediatric Hospital, Instituto Mexicano del Seguro Social, México, DF, Mexico
}

Mukherjee et al (1968) described a boy with multiple anomalies, unusual dermatoglyphics, and an extra metacentric chromosome. We report here a patient with very similar clinical, dermatoglyphic, and cytological findings.

\section{Case Report}

The patient, an 11-year-old boy was born of a fullterm pregnancy complicated by persistent emesis in the mother. Labour lasted 8 hours and apnoea was present for 5 minutes. The birthweight was $1800 \mathrm{~g}$. Growth and development were retarded. He raised his head at 6 months, sat up alone at 15 months, and walked at age $3 \frac{1}{2}$ years. Speech is essentially monosyllabic and he can say no more than 3 or 4 simple words. There is urinary and faecal incontinence.

On examination at the age of 11 years, he was an obviously retarded child with asymmetrical facies, microcephally, and a long thin body habitus. Weight was $30.5 \mathrm{~kg}$; height $138.5 \mathrm{~cm}$; and head circumference $49 \mathrm{~cm}$. The face was bird-like and asymmetrical with the left side being larger than the right (Fig. 1). The ears were positioned normally, but were small and misshapen. A high arched palate was present. Cardiac and abdominal examination were unremarkable. The penis was normal but the testes were not in the scrotum. Marked spasticity with hyperactive deep tendon reflexes and clonus were found in the arms and legs. Babinski responses were present. There were bilateral flexion contractures of the third and fourth fingers and the Achilles tendons.

IQ was estimated to be 36 at age 9 years and 42 at age 11 years (Therman-Merrill test).

Results of routine examination of the blood and urine were within the limits of normal. Electrocardiogram and chest $x$-ray were normal. An intravenous pyelogram was normal. The electroencephalogram showed generalized abnormal subcortical activity especially in the parietal and occipital regions.

The mother and father were 32 and 46 years of age respectively at the time of birth of the propositus. At

Received 4 September 1970.

* Present address: Department of Medical Genetics, Hospital de Pediatría, Centro Médico Nacional, Av. Cuauhtémoc 330, México
7, DF, Mexico. age 41 years the mother had a subtotal thyroidectomy, but the pathology report is not available. One of the mother's 8 pregnancies terminated in spontaneous abortion in the first trimestrer. The proband's 6 sibs are normal. A brother of the mother is said to have died with leukaemia.

No abnormalities were detected in blood groups, serum proteins, or red cell 6-phosphogluconate dehydrogenase in the proband and his parents.

\section{Cytological Studies}

Sex Chromatin. Over 500 nuclei from the buccal mucosa were examined and no sex chromatin bodies were observed.

Chromosomes. Peripheral blood lymphocytes were studied (Moorhead et al, 1968) from the parents and sibs and no abnormalities were detected.

The proband's blood cells were examined on two separate ocassions. Of the 45 cells evaluated, 40 contained 47 chromosomes with an extra small metacentric chromosome without satellites (Fig. 2). Three cells had 46 and two cells had 45 chromosomes but the loss of chromosomes was random and each cell also had the abnormal metacentric chromosome.

Autoradiography (Schmid, 1963) showed normal replicating patterns in the proband. The extra metacentric was not late replicating.

\section{Dermatoglyphs}

The flexion contractures of the fingers precluded the preparation of adequate palm prints. However, on direct examination the following patterns were seen. Right hand: UL UL UL W UL; axial triradius in $t^{\prime \prime}$; double loop on the hypothenar region; loop in $\mathrm{I}_{3}$. Left hand: UL UL RL W A; axial triradius in $t^{\prime}$; double loop on the hypotenar region, loop in $\mathrm{I}_{3}$.

The arch on the 5th finger of the left hand, the radial loop on the 3rd finger of the left hand, and the double loops in the hypothenar regions are particularly uncommon in controls (less than 2\%). Double loops or whorls were found in the hypothenar regions on both palms in $0.4 \%$ of 250 normal Mexican males (Zavala, González, and Lisker, 1969). 


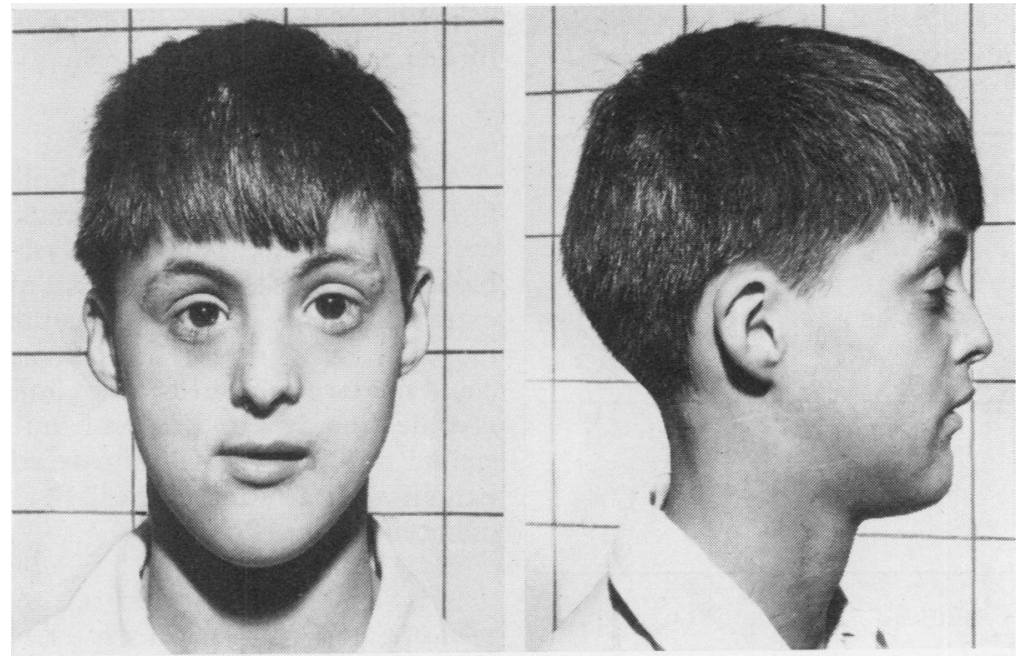

Fig. 1. The patient at the age of 11 years.

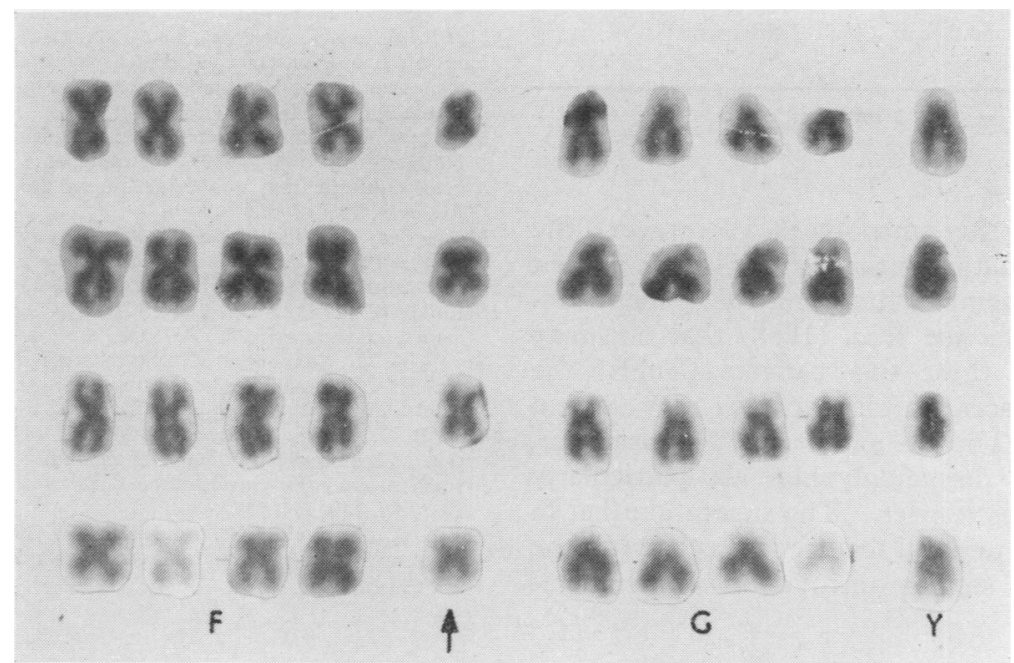

Fig. 2. Partial karyotype of the $\mathrm{F}$ and $\mathrm{G}$ groups including the $\mathrm{Y}$ chromosome and the abnormal small metacentric chromosome (arrow) from 4 different metaphases.

\section{Discussion}

Seven patients with extra small metacentric chromosomes have been reported previously (Frøland, Holst, and Terslev, 1963; Gustavson, Atkins, and Patricks, 1964; Taft, Dodge, and Atkins, 1965; Smith et al, 1965; Hultén et al, 1966; Mukherjee et al, 1968; Ishmael and Laurence, 1968) and although the morphology of the unusual chromosome was similar in all cases the clinical characteristics were extremely varied. One ex- planation for this could be that the origin of the metacentric chromosome varied from case to case. In the case reported here and in the previous cases it was not possible to establish the origin of the abnormal chromosome. Autoradiographic and sex chromatin studies make it unlikely to be derived from an X chromosome.

Another possible explanation for the marked variation in clinical findings in the cases previously reported is that the abnormal chromosomes were 
TABLE

COMPARISON OF CLINICAL FEATURES IN TWO CASES WITH A SMALL EXTRA METACENTRIC AUTOSOME

\begin{tabular}{|c|c|c|}
\hline Clinical Features & $\begin{array}{c}\text { Mukherjee } \\
\text { et al } \\
\text { (1968) }\end{array}$ & Present Case \\
\hline $\begin{array}{l}\text { Sex } \\
\text { Age (yr) } \\
\text { Low birth weight } \\
\text { Long thin body habitus } \\
\text { Mental retardation } \\
\text { Speech not developed } \\
\text { Abnormal electro-encephalogram }\end{array}$ & $\begin{array}{l}\mathbf{M} \\
\mathbf{8} \\
+ \\
+ \\
+ \\
+ \\
\mathbf{O}\end{array}$ & $\begin{array}{l}M \\
11 \\
+ \\
+ \\
+ \\
+ \\
+\end{array}$ \\
\hline $\begin{array}{l}\text { Head } \\
\text { Microcephaly } \\
\text { Facies asymmetrical } \\
\text { Bird-like facies } \\
\text { Abnormal ears } \\
\text { High palate } \\
\text { Scoliosis }\end{array}$ & $\begin{array}{l}+ \\
+ \\
+ \\
+ \\
+ \\
+\end{array}$ & $\begin{array}{l}+ \\
+ \\
+ \\
+ \\
+ \\
+\end{array}$ \\
\hline $\begin{array}{l}\text { Extremities } \\
\text { Spasticity } \\
\text { Slender arms and fingers } \\
\text { Brisk tendon jerks (clonus) } \\
\text { Contracted Achilles tendons } \\
\text { Talipes }\end{array}$ & $\begin{array}{c}+ \\
+ \\
+ \\
+ \\
\text { Equinus }\end{array}$ & $\begin{array}{c}+ \\
+ \\
+ \\
+ \\
\text { Equinus cavus }\end{array}$ \\
\hline $\begin{array}{l}\text { Uncommon digital patterns } \\
\text { Whorls on hypotenar regions } \\
\text { Abnormal renal system } \\
\text { Incontinence (urinary and faecal) } \\
\text { Undescended testes }\end{array}$ & $\begin{array}{l}+ \\
+ \\
\stackrel{+}{N S} \\
\text { O }\end{array}$ & $\begin{array}{l}+ \\
+ \\
\mathbf{O} \\
+ \\
+\end{array}$ \\
\hline
\end{tabular}

$+=$ present $; O=$ absent $;$ NS $=$ not stated.

not related to the phenotypes. However, the clinical and dermatoglyphic findings in our patient so strikingly resemble those in the patient described by Mukherjee et al (1968) that one may suggest that in these two patients (Table) the extra small metacentric chromosome may have a similar origin. The distinctive facial appearance, asymmetry, and dermatoglyphics are particularly remarkable in this respect. The suggestion that in both cases these unusual features are related to the morphologically similar uncommon extra meta- centric chromosome would be strengthened by further reports of similar cases.

\section{Summary}

An 11-year-old boy with multiple congenital malformations and severe mental retardation has been described. Chromosome analysis of peripheral blood leucocytes showed a modal number of 47 , the extra chromosome being a small metacentric chromosome. The origin of the extra chromosome could not be established. The clinical and dermatoglyphic findings in the proband are remarkably similar to those previously described in another patient with a morphologically similar extra small metacentric chromosome.

\section{REFERENCES}

Frøland, A., Holst, G., and Terslev, E. (1963). Multiple anomalies associated with an extra small autosome. Cytogenetics, 2, 99-106.

Gustavson, K.-H., Atkins, L., and Patricks, I. (1964). Diverse chromosomal anomalies in two siblings. Acta Paediatrica (Stockholm), 53, 371-387.

Hultén, M., Lindsten, J., Fraccaro, M., Mannini, A., and Tiepolo, L. (1966). Extra minute chromosome in somatic and germ-line cells of the same person. Lancet, 2, 22-24.

Ishmael, J. and Laurence, K. M. (1968). An extra small metacentric chromosome in a mentally retarded boy. Fournal of Medical Genetics, 5, 335-340.

Moorhead, P. S., Nowell, P. C., Mellman, W. J., Battips, D. M., and Hungerford, D. A. (1960). Chromosome preparations of leukocytes cultured from human peripheral blood. Experimental Cell Research, 20, 613-616.

Mukheriee, A. B., Partington, M. W., Simpson, N. E., and Walmsley, K. A. (1968). Multiple anomalies associated with a small extra metacentric autosome. Fournal of Medical Genetics, 5, 329-334.

Schmid, W. (1963). DNA replication patterns of human chrom.osomes. Cytogenetics, 2, 175-193.

Smith, K. D., Steinberger, E., Steinberger, A., and Perloff, W. H., (1965). A familial centric chromosome fragment. Cytogenetics, 4, 219-226.

Taft, P. D., Dodge, P. R., and Atkins, L. (1965). Mental retardation and multiple congenital anomalies. Association with extra small metacentric chromosome. American fournal of Disease of Children, 109, 554-557.

Zavala, C., González, G. and Lisker, R. (1969). Dermatoglyphic patterns in a sample of normal urban Mexicans. Human Heredity, 19, 534-539. 